\title{
NINE YEAR RESULTS OF GROWTH AND YIELDING ESTIMATION OF SIX SCAB-RESISTANT APPLE CULTIVARS GRAFTED ON THREE DWARFING ROOTSTOCKS IN INTEGRATED FRUIT PRODUCTION
}

\author{
Alojzy Czynczyk, Paweł Bielicki, Augustyn Mika \\ and Adam Krawiec
}

\author{
Research Institute of Horticulture, Pomology Department \\ Pomologiczna 18, 96-100 Skierniewice, POLAND \\ e-mail: alojzy.czynczyk@inhort.pl
}

(Received March 23, 2012/Accepted May 5, 2012)

\section{A B S T R A C T}

During the nine years (2002-2010) 6 apple cultivars, scab-resistant or partially resistant to apple scab: 'Bohemia', 'Topaz', 'Rubinola', 'Goldstar', 'Pinova' and 'Redkroft' grafted on 3 dwarfing rootstock: M.9, P 22 and P 60, were tested at the Experimental Orchard in Dąbrowice with integrated fruit production. The susceptibility to apple canker (Nectria sp.), apple scab and powdery mildew, as well as growth, yielding, fruit quality and damage by pests were observed. After 9 years, the highest number of infected trees, on trunks and branches, were observed on the cultivars: 'Topaz', 'Bohemia', and 'Redkroft'. All the cultivars grafted on P 60 rootstocks formed the largest trees, whereas on P 22 the smallest. The highest yields were obtained from all the cultivars grown on P 60 and the smallest on P 22. The cropping efficiency index was the highest for: 'Bohemia', 'Rubinola', 'Goldstar' and 'Pinova' on P 22. 'Topaz' had the highest cropping efficiency on P 60 and 'Redkroft' on M.9 and P 60. In the last three years (2008-2010), the effect of rootstock on fruit quality was minimal and not significant. Apple scab and powdery mildew, and some important pests, were not observed after applying on integrated system of spraying. The apple cultivars: 'Bohemia', 'Rubinola', 'Topaz 'and 'Redkroft' are the most promising for processing and amateur orchards with the integrated system of management. The cultivars: 'Pinova' and 'Goldstar' should not be recommended for growing on light soil in the integrated system of production. The fruits of 'Goldstar' are susceptible to bitter pit.

Key words: apple, scab-resistant cultivars, rootstock, integrated fruit production, susceptibility to apple canker, size of trees, yielding 


\section{INTRODUCTION}

The most valuable apple cultivars with high a productivity index are recommended for planting in commercial orchards. Scab-resistant apple cultivars, such as: 'Ariwa', 'Topaz', 'Freedom', 'Rajka', 'Novamac' and others, are most recommended for planting when establishing new organic orchards to produce fruits for processing (Czynczyk, 1996; Blażek, 2004; Kruczyńska, 2007). For orchards producing fruits for processing, very promising are also new cultivars: 'Rewena', 'Reanda' and 'Remo' bred in Germany, which are resistant to three diseases: apple scab, powdery mildew and fire blight (Fisher and Fisher, 2004; Kruczyńska, 2008). Other cultivars, scab-resistant and partially scabresistant, that are attractive and accepted by consumers, such as: 'Rubinola', 'Ecolette', 'Enterprice', 'Pinova', 'Redkroft', 'Gold Milenium', 'Free Redstar', 'Bohemia' and 'Santana', could be planted in amateur home gardens with a minimal effort to control diseases (Sansavini et al., 2004; Żurawicz et al., 2004; Kruczyńska, $2007,2008)$. The production of scabresistant apple trees in Polish nurseries had been increasing each year and in 2011 reached a level above 148 thousand trees, which constitutes nearly $2.4 \%$ of the total production of apple trees in nurseries. The most commonly produced scab-resistant apple cultivars in 2010 were: 'Ariwa' (62.0 thousand), 'Topaz' (45.5 thousands), 'Rubinola' (22.4 thousands) and 'Rajka' (12.0 thousands). In the years to come, the share of scab- resistant or partially scab-resistant apple cultivars will increase because some of them, such as: 'Gold Milenium', 'Free Redstar', 'Ecolette', 'Santana' or 'Enterprise', should be planted more and more in amateur gardens with minimal regiments for controlling diseases (Żurawicz et al., 2004; Kruczyńska, 2008; Sosna, 2005). The aim of this experiment was to evaluate good dwarfing rootstocks for scab-resistant and partially scab-resistant cultivars, which are recommended for integrated fruit production. The purpose of this confirmation of the study was tree productivity and fruit quality of apple trees in a fully cropping period under the integrated system of orchard management. Previous results from this study for the period 2002-2004 were published by Czynczyk et al. (2005). The results from this study should inform readers which dwarfing rootstock could be most useful for the tested light soil.

\section{MATERIAL AND METHODS}

The experiment was set up in the spring of 2002 in the Experimental Orchard in Dąbrowice, near Skierniewice belonging to the Research Institute of Pomology and Floriculture, situated in central Poland. Twoyear-old trees of scab-resistant or partially scab-resistant apple cultivars with one-year-old crown were used to establish the trial. Six cultivars: 'Bohemia', 'Rubinola', 'Topaz', 'Goldstar', 'Pinova' and 'Redkroft' grafted on three dwarfing rootstocks M.9, P 22 and P 60 were chosen for the study. Tree on M.9 commonly used in 
Poland and Western Europe were used as the standard. The trial was set up in podsolic soil overlaying heavy clay in a randomized block design with four replicates and three trees per plot, where for over fifty years various species of fruit trees had been grown. Each cultivar under various product of mulching was presented by 12 trees. Trees on M.9 were planted $3.40 \times 1.35$ meters apart, trees on P 22 were planted $3.40 \times 0.80$ meters apart and trees on P 60 were planted $3.40 \mathrm{x}$ 1.45 meters apart. All the trees were trained as slender spindles. Fertilization, soil management, disease and pest control were carried out in accordance with the Integrated Fruit Production guidelines. Infection with apple scab was recorded using a ranking scale recommended by Borecki and Mrozowska (1961). Mildew was controlled by cutting away infected shoots in early spring and during the vegetative period. All trees were drip irrigated from the time of planting. The following measurements were taken: number of trees infected with Nectria sp. and size of necrosis, tree trunk circumference measured at $30 \mathrm{~cm}$ above ground and converted to trunk cross sectional area, fruit yield per tree and weight of fruits. In the last three years (2008-2010) records were kept of the percentage of fruits with diameter over $7 \mathrm{~cm}$ and of the percentage of fruits with a blush on more than $50 \%$ of skin surface. All fruit samples were taken from one representative tree from each plot to evaluate the diameter and size of blush on fruits. The size of trees, weight and diameter of fruits and size of the blush area were assessed using on electronic sorting machine manufactured by Greef. The results were statistically evaluated separately for each cultivar with analyses of variance, followed by Duncan's multiple range test at $\mathrm{p}=0.05$.

\section{RESULTS AND DISCUSSION}

Tree health. During the nineyear period (2002-2010) of growth there was no loss of trees caused by winter frost, either affecting the root system or the part of tree above ground. In the same period, some trees died due to serious apple tree canker (Nectria sp.) infection that occurred on trunks and branches. The highest number of lost trees was recorded for 'Topaz' (5 trees). One lost tree was recorded for 'Bohemia', 'Rubinola' and 'Redkroft'. 'Bohemia', 'Goldstar' and 'Redkroft' also had the largest mean size of necrotic lesions on branches and trunks. Among the tree of 'Pinova' cultivar no necrotic lesions were recorded (Tab. 1). The highest susceptibility of 'Topaz' and 'Goldstar' to canker confirms the results obtained earlier by Blażek (2004), Jönsson and Tahir (2004) and Czynczyk et al. (2008, 2011). This rate of tree loss and the size of necrotic lesions on some trees were much lower than in the neighbouring experiment with the organic system of management (Czynczyk et al., 2011). The high susceptibility of some scab-resistant cultivars to apple canker must be taken into consideration when planting trees in orchards located in the region with high humidity. 
A. Czynczyk et al.

Table 1. The number of lost and infected trees (out of 12) due to apple canker (Nectria sp.) and total size of basal necrosis in 2010 after 9 years of growing

\begin{tabular}{|c|c|c|c|c|}
\hline Cultivar & Rootstock & $\begin{array}{l}\text { Number of trees } \\
\text { lost due to infec- } \\
\text { tion with canker }\end{array}$ & $\begin{array}{l}\text { Number of } \\
\text { infected trees }\end{array}$ & $\begin{array}{l}\text { Size of necro- } \\
\text { sis on infected } \\
\text { trees }\left[\mathrm{cm}^{2}\right]\end{array}$ \\
\hline \multirow{3}{*}{ Bohemia } & M.9 & 0 & 1 & 49 \\
\hline & P 22 & 1 & 2 & 145 \\
\hline & P 60 & 0 & 0 & 0 \\
\hline \multirow{3}{*}{ Rubinola } & M.9 & 0 & 1 & 80 \\
\hline & P 22 & 0 & 0 & 0 \\
\hline & P 60 & 1 & 0 & 0 \\
\hline \multirow{3}{*}{ Topaz } & M.9 & 2 & 1 & 90 \\
\hline & P 22 & 1 & 0 & 0 \\
\hline & P 60 & 2 & 0 & 0 \\
\hline \multirow{3}{*}{ Goldstar } & M.9 & 0 & 1 & 30 \\
\hline & P 22 & 0 & 1 & 20 \\
\hline & P 60 & 0 & 1 & 30 \\
\hline \multirow{3}{*}{ Pinova } & M.9 & 0 & 0 & 0 \\
\hline & P 22 & 0 & 0 & 0 \\
\hline & P 60 & 0 & 0 & 0 \\
\hline \multirow{3}{*}{ Redkroft } & M.9 & 0 & 3 & 184 \\
\hline & P 22 & 1 & 1 & 120 \\
\hline & P 60 & 0 & 0 & 0 \\
\hline
\end{tabular}

Tree vigour. After nine years of growth all the cultivars proved to be most vigorous on rootstock $P 60$. The weakest growing trees of all the cultivars were on $\mathrm{P} 22$. The most vigorously grooving cultivars were 'Rubinola' and 'Bohemia', and the weakest 'Goldstar' and 'Redkroft'. The ranking of growth vigour of these cultivars was similar to that reported earlier by (Czynczyk et al., 2008 and 2011; Kruczyńska, 2008).

Yielding. The yields obtained in 2007 and 2009 were reduced by severe spring frosts. The high yields expected in 2010 after successful blossoming were also reduced by heavy hand-thinning of fruitlets. After nine years (2002-2010) of growth, the highest cumulative yields were obtained from all the cultivars grown on $\mathrm{P} 60$ and the smallest on P 22, except 'Goldstar' and 'Bohemia', which produced the lowest yield on M.9. 'Pinova' and 'Topaz' produced the highest yields on all the tested rootstocks and 'Bohemia' and 'Redkroft' - the lowest (Tab. 2). It should be emphasized that the yields of all the tested cultivars on M.9 in this experiment were much higher than the yields of those cultivars obtained in the neighbouring experiment with the organic system of management (Czynczyk et al., 2011). The yielding efficiency index, expressed in $\mathrm{kg}$ per $1 \mathrm{~cm}^{2}$ of trunk crosssection area (TCSA) was the highest for 'Bohemia', 'Rubinola', 'Goldstar' and 'Pinova' on P 22. 'Topaz' had the highest yielding efficiency from 
Table 2. Trunk cross-sectional area (TCSA), cumulative yield, cropping efficiency coefficient (CEC) and fruit quality parameters in six scab-resistant apple cultivars grafted on three dwarfing rootstocks in 2010

\begin{tabular}{|c|c|c|c|c|c|c|c|}
\hline \multirow[b]{2}{*}{ Cultivar } & \multirow[b]{2}{*}{ Rootstock } & \multirow{2}{*}{$\begin{array}{l}\text { TCSA } \\
{\left[\mathrm{cm}^{2}\right]}\end{array}$} & \multicolumn{3}{|c|}{ Yield [kg/tree] } & \multirow{2}{*}{$\begin{array}{c}\mathrm{CEC} \\
{\left[\mathrm{kg} / \mathrm{cm}^{2}\right]}\end{array}$} & \multirow{2}{*}{$\begin{array}{l}\text { Weight of } \\
100 \text { fruits } \\
{[\mathrm{kg}]}\end{array}$} \\
\hline & & & $\begin{array}{l}2002- \\
2004\end{array}$ & $\begin{array}{c}2005- \\
2010\end{array}$ & $\begin{array}{l}2002- \\
2010\end{array}$ & & \\
\hline \multirow{3}{*}{ Bohemia } & M.9 & $71.1 \mathrm{~b}$ & $2.9 \mathrm{~b}$ & $42.1 \mathrm{a}$ & $44.7 \mathrm{a}$ & $0.7 \mathrm{a}$ & $18.6 \mathrm{a}$ \\
\hline & P 22 & $41.0 \mathrm{a}$ & $7.6 \mathrm{c}$ & $47.1 \mathrm{a}$ & $54,3 \mathrm{a}$ & $1.9 \mathrm{~b}$ & $17.0 \mathrm{a}$ \\
\hline & P 60 & $72.4 \mathrm{~b}$ & $0.7 \mathrm{a}$ & $74.6 \mathrm{~b}$ & $76,5 b$ & $1.2 \mathrm{ab}$ & $18.2 \mathrm{a}$ \\
\hline \multirow{3}{*}{ Rubinola } & M.9 & $75.8 b$ & $4.8 \mathrm{a}$ & $62.1 \mathrm{~b}$ & $66.9 \mathrm{a}$ & $0.9 \mathrm{a}$ & $16.2 \mathrm{a}$ \\
\hline & P 22 & $49.6 a$ & $7.9 \mathrm{~b}$ & $49.2 \mathrm{a}$ & $56.4 \mathrm{a}$ & $1.3 \mathrm{a}$ & $15.5 \mathrm{a}$ \\
\hline & P 60 & $77.2 \mathrm{~b}$ & $2.7 \mathrm{a}$ & $67.0 \mathrm{~b}$ & $69.1 \mathrm{a}$ & $1.1 \mathrm{a}$ & $16.2 \mathrm{a}$ \\
\hline \multirow{3}{*}{ Topaz } & M.9 & $54.3 \mathrm{a}$ & $10.0 \mathrm{ab}$ & $76.0 \mathrm{~b}$ & $86.0 \mathrm{a}$ & $1.6 \mathrm{a}$ & $15.4 \mathrm{a}$ \\
\hline & P 22 & $53.8 \mathrm{a}$ & $13.5 b$ & $58.5 \mathrm{a}$ & $72.1 \mathrm{a}$ & $1.5 \mathrm{a}$ & $15.4 \mathrm{a}$ \\
\hline & P 60 & $61.1 \mathrm{a}$ & $8.1 \mathrm{a}$ & $90.7 b$ & $104.7 \mathrm{~b}$ & $1.8 \mathrm{a}$ & $14.1 \mathrm{a}$ \\
\hline \multirow{3}{*}{ Goldstar } & M.9 & $21.4 \mathrm{a}$ & $5.9 \mathrm{a}$ & $33.1 \mathrm{a}$ & $39.0 \mathrm{a}$ & $2.1 \mathrm{ab}$ & $13.7 \mathrm{a}$ \\
\hline & P 22 & $29.6 a$ & $7.4 \mathrm{ab}$ & $63.4 b$ & $70.8 b$ & $2.4 \mathrm{~b}$ & $14.2 \mathrm{a}$ \\
\hline & P 60 & $50.4 \mathrm{~b}$ & $7.8 \mathrm{~b}$ & $81.8 \mathrm{c}$ & $89.6 \mathrm{c}$ & $1.9 \mathrm{a}$ & $14.5 \mathrm{a}$ \\
\hline \multirow{3}{*}{ Pinova } & M.9 & $46.1 \mathrm{~b}$ & $12.3 \mathrm{a}$ & $98.6 b$ & $110.9 \mathrm{~b}$ & $2.4 \mathrm{a}$ & $13.5 \mathrm{a}$ \\
\hline & P 22 & $27.2 \mathrm{a}$ & $12.5 \mathrm{a}$ & $65.0 \mathrm{a}$ & $77.5 \mathrm{a}$ & $3.0 \mathrm{~b}$ & $12.3 \mathrm{a}$ \\
\hline & P 60 & $54.7 \mathrm{c}$ & $14.9 \mathrm{a}$ & $121.9 \mathrm{c}$ & $136.4 \mathrm{c}$ & $2.5 \mathrm{ab}$ & $12.3 \mathrm{a}$ \\
\hline \multirow{3}{*}{ Redkroft } & M.9 & $32.4 \mathrm{a}$ & $10.2 b$ & $45.7 \mathrm{a}$ & $55.9 \mathrm{a}$ & $1.8 \mathrm{~b}$ & $17.1 \mathrm{a}$ \\
\hline & P 22 & $39.0 \mathrm{ab}$ & $7.2 \mathrm{a}$ & $39.3 a$ & $46.4 \mathrm{a}$ & $1.3 \mathrm{a}$ & $16.1 \mathrm{a}$ \\
\hline & P 60 & $42.8 b$ & $9.8 \mathrm{ab}$ & $66.8 \mathrm{~b}$ & $76.9 \mathrm{~b}$ & $1.8 \mathrm{~b}$ & $15.5 \mathrm{a}$ \\
\hline
\end{tabular}

trees grafted on P 60 and 'Redkroft' on M.9 and P 60. The lowest cropping efficiency index had cultivars: 'Bohemia', 'Rubinola' and 'Goldstar' grafted on M.9 and the 'Topaz' and 'Redkroft' from trees grafted on P 22. In the last three years (2008-2010), the choice of rootstock had no effect on the size of fruits of all the cultivars tested (Tab. 3). The percentage of fruits with diameter over $7 \mathrm{~cm}$ was high for all the cultivars except ' $\mathrm{Pi}$ nova' in the years 2008 and 2010. High yields of this cultivar had a negative effect on fruit size. The size of fruits of all the cultivars except ' $\mathrm{Pi}$ nova' was good and will be accepted by Polish consumers. Light sandy soil is not suitable for growing the 'Pinova' cultivar commercially. In the last three years the colouring of fruits of all the cultivars except 'Goldstar' and 'Pinova' in 2008 were quite good and on average reached an area of over $50 \%$. Best coloured fruits were picked each year from trees of the cultivars 'Topaz', 'Rubinola' and 'Bohemia'. The lowest area covered by blush was on the fruits of the cultivars 'Goldstar' and 'Pinova' (Tab. 3). These results agree with earlier reports presented by Czynczyk et al. (2008 and 2011) and Sosna (2005). Apple scab and powdery mildew were not observed. Same important pests such as: codling moths (Cydia pomonella), aphids and 


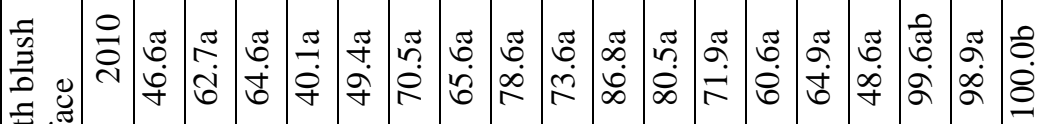

胥

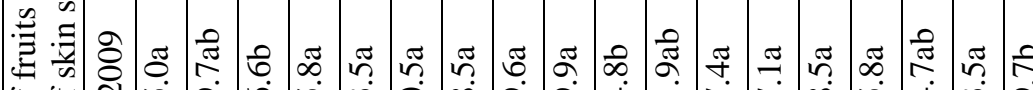
世 $\sin _{0}$

岂

ڤ் - त

을



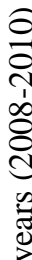

吾

ప్ర

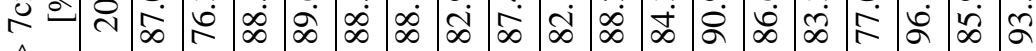

$\stackrel{\sim}{\sim}$

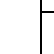



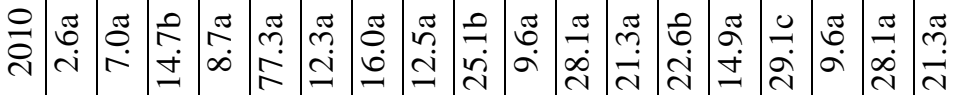



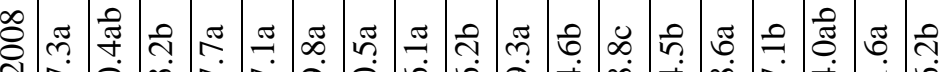
ก

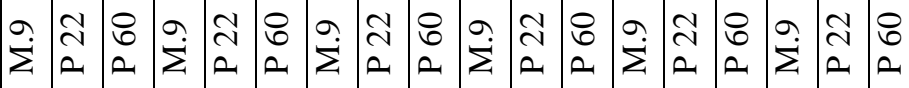

$\frac{y}{0}$
$\frac{0}{0}$
$\frac{0}{0}$
0

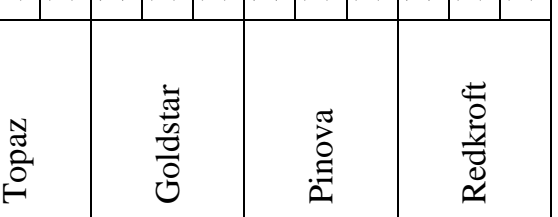




\section{...growth and yielding of six scab-resistant apple cultivars...}

spiders were also not observed. The standard program of spraying recommended in orchards with the integrated system of management was fully successful in keeping all diseases and pests at a very low level.

\section{REFERENCES}

Blażek J. 2004. Response to diseases in new apple cultivars from the Czech Republic. J. FRUIT ORNAM. PLANT RES. 12: 241-250.

Borecki Z., Mrozowska T. 1961. Zwalczanie grzyba Venturia inaequalis (Cooke) Aderch. metodą chemiczną na odmianach jabłoni o różnym stopniu wrażliwości. PRACE INST. SAD. 5: 271-285.

Czynczyk A. 1996. Więcej uwagi na odmiany parchoodporne. Międzynarodowe Sympozjum - Ekologia w Ogrodnictwie. 30.05-01.06.1996 ART. Olsztyn, pp. 12-16.

Czynczyk A., Bielicki P., Mika A., Krawiec A. 2005. Growth and yielding of six scab-resistant apple cultivars grafted on three dwarfing rootstocks in integrated production. J. FRUIT ORNAM. PLANT RES. 13: 19-23.

Czynczyk A., Mika A., Bielicki P., Krawiec A. 2008. Suitability evolution of several apple cultivars for organic fruit production. J. FRUIT ORNAM. PLANT RES. 16: 7-15.

Czynczyk A., Bielicki P., Mika A., Krawiec A. 2011. A nine-year evaluation of several scab-resistant apple cultivars for organic fruit production. J.
FRUIT ORNAM. PLANT RES. 19(2) 2011: 87-97.

Fisher M., Fischer Ch. 2004. Genetic resource sass basis for new resistant apple cultivar. J. FRUIT ORNAM. PLANT RES. 12: 63-76.

Jonsson A., Tahir J. 2004. Evaluation of scab-resistant apple cultivars in Sweden J. FRUIT ORNAM.PLANT RES. (Spec. ed.) 12: 223-232.

Kruczyńska D. 2007. Odmiany jabłoni i gruszy przydatne do sadów ekologicznych. Ogólnopolska Konferencja Sadownicza. Odmiany i podkładki roślin sadowniczych do upraw ekologicznych. ISK Skierniewice, 21 listopada 2007, pp. 19-23.

Kruczyńska D. 2008. Nowe odmiany jabłoni. Hortpress Sp. z o. o., pp. 214.

Sansavini S., Donati F., Costa F., Tartarini S. 2004. Advances in apple breeding for enhanced fruit quality and resistant to biotic stresses: new varieties for the European market J. FRUIT ORNAM. PLANT RES. 12: 13-52.

Sosna J., 2005. Growth and cropping of several scab-resistant apple cultivars on six rootstocks. ACTA SCI POL. HORTORUM CULTUS 4(1): 109118.

Żurawicz E., Lewandowski M., BednarekNiemiec A., Rutkowski K., 2004. Preliminary results on the production value of scab resistant apple cultivars bred at the Research Institute of Pomology and Floriculture (RIPF). Skierniewice, Poland. ACTA HORT. 663: 879-882. 


\title{
DZIEWIĘCIOLETNIE WYNIKI WZROSTU I OWOCOWANIA SZEŚCIU PARCHOODPORNYCH ODMIANACH JABŁONI SZCZEPIONYCH NA TRZECH SŁABO ROSNACCYCH PODKŁADKACH W SADZIE Z INTEGROWANĄ PRODUKCJĄ OWOCÓW
}

\author{
Alojzy Czynczyk, Paweł Bielicki, Augustyn Mika \\ i Adam Krawiec
}

S T R E S Z C Z E N I E

W okresie 9 lat (2002-2010) 6 parchoodpornych lub częściowo odpornych na parcha odmian jabłoni: Bohemia, Rubinola, Topaz, Goldstar, Pinova i Redkroft szczepionych na 3 słabo rosnących podkładkach: M.9, P 22 i P 60 badano w Sadzie Doświadczalnym w Dąbrowicach w doświadczeniu z integrowaną produkcja owoców. Badaniami objęto podatność jabłoni na porażenie przez raka jabłoni (Nectria sp.), parcha i mączniaka jabłoni, oraz siłę wzrostu, owocowanie i jakość owoców, a także porażenie owoców przez najważniejsze szkodniki jabłoni. Po 9 latach wzrostu najsilniej porażone przez raka jabłoni były drzewa 'Topaz', 'Redkroft' i 'Bohemia', a nie porażone były drzewa 'Pinova'. Najsilniejszym wzrostem odznaczały się wszystkie odmiany szczepione na P 60, a najsłabszym na P 22. Najwyższą sumę plonów zebrano $\mathrm{z}$ badanych odmian na $\mathrm{P}$ 60, a najniższą na $\mathrm{P} 22$. Najwyższy wskaźnik plenności miały odmiany Bohemia, Rubinola, Goldstar i Pinova na P 22, a Topaz i Redkroft na P 60. W ostatnich trzech latach (2008-2010) wpływ podkładek na masę owoców i wielkość rumieńca był nieistotny. Przy stosowaniu integrowanego programu ochrony nie obserwowano występowania objawów parcha i mączniaka jabłoni, a także żerowania ważniejszych szkodników jabłoni. Po 9 latach obserwacji (20022010) odmiany Rubinola, Topaz, 'Bohemia i Redkroft są najbardziej przydatne do integrowanej uprawy $\mathrm{w}$ sadach przydomowych i przemysłowych produkujących owoce dla potrzeb przetwórstwa. Odmiany Pinova i Goldstar nie powinny być polecane do uprawy na lekkich glebach. Owoce 'Goldstar' są ponadto podatne na gorzką plamistość podskórną.

Słowa kluczowe: jabłoń, parchoodporne odmiany, podkładka, wrażliwość na mączniaka drzew owocowych, wielkość drzew, owocowanie, integrowana produkcja owoców 